\title{
Pengaruh Sosialisasi Pajak Terhadap Realisasi Penerimaan Pajak dengan Kepatuhan Wajib Pajak Sebagai Variabel Intervening
}

\author{
Herin Arlinda Yonita Sari \\ Universitas Negeri Malang \\ Malang, Indonesia \\ herinarlinda99@gmail.com
}

\author{
Makaryanawati \\ Universitas Negeri Malang \\ Malang, Indonesia \\ makaryanawati.fe@um.ac.id
}

\author{
Ferby Mutia Edwy \\ Universitas Negeri Malang \\ Malang, Indonesia \\ ferby.edwy.fe@um.ac.id
}

Corresponding Author : Ferby Mutia Edwy

Submitted: 27 Juli 2020

Accepted: 22 Agustus 2020

Published: 22 Agustus 2020

\begin{abstract}
ABSTRAK
Penelitian ini bertujuan untuk mengetahui: (1) pengaruh Sosialisasi Pajak terhadap Kepatuhan Wajib Pajak, (2) pengaruh Sosialisasi pajak terhadap Realisasi Penerimaan Pajak, (3) pengaruh Kepatuhan Wajib Pajak terhadap Realisasi Penerimaan Pajak, serta (4) pengaruh Sosialisasi pajak terhadap Realisasi Penerimaan Pajak melalui Kepatuhan Wajib Pajak sebagai variabel intervening. Penelitian ini menggunakan rancangan penelitian kuantitatif eksplanatori. Data penelitian merupakan data sekunder selama 5 tahun dari tahun 2004 sampai 2018 dengan teknik pengumpulan data menggunakan dokumentasi. Data yang digunakan dalam penelitian adalah sosialisasi pajak, realisasi penerimaan pajak dan kepatuhan wajib pajak yang bersumber dari Kantor Pelayanan Pajak Pratama Kepanjen. Data tersebut diolah dengan menggunakan analisis jalur (path). Hasil penelitian menunjukan bahwa: (1) sosialisasi pajak berpengaruh secara positif terhadap kepatuhan wajib pajak, (2) sosialisasi pajak berpengaruh secara positif terhadap realisasi penerimaan pajak, (3) kepatuhan wajib pajak berpengaruh secara positif terhadap realisasi penerimaan pajak, (4) sosialisasi pajak berpengaruh secara positif terhadap realisasi penerimaan pajak melalui kepatuhan wajib pajak
\end{abstract}

Keywords : Sosialisasi Pajak, Realisasi Penerimaan Pajak, Kepatuhan Wajib Pajak, Theory of Planned Behaviour (TPB)

I. PENDAhULUAN

\subsection{Latar Belakang masalah}

Pajak memiliki peran dominan bagi negara karena pajak merupakan sumber penerimaan negara terbesar (Yusuf Kastolani \& Ardiyanto, 2017). Pembangunan dapat terlaksana sesuai yang direncanakan, apabila penerimaan 
pajak dapat mencapai target. Namun, fakta tiga tahun terakhir mengatakan bahwa penerimaan pajak tidak pernah mencapai target (Suryowati, 06 Desember 2017). Tahun 2015 penerimaan pajak hanya mencapai 1055 Triliun atau 81,5\% dari target sebesar 1294,25 Triliun. Tahun 2016 penerimaan pajak hanya mencapai 1105 Triliun atau $81,54 \%$ dari target sebesar 1539,2 Triliun. Tahun 2017 penerimaan pajak hanya mencapai 1339 Triliun atau sebesar $91 \%$ dari target sebesar 1489,9 Triliun. Banyak faktor yang membuat realisasi penerimaan pajak tidak mencapai target, salah satunya adalah karena sistem pemungutan pajak di Indonesia menganut Self Assessement System yang menguji kejujuran wajib pajak dalam memberikan kewajibannya membayar pajak (Darmayani \& Herianti, 2017).

Penerapan Self Assessement System dilakukan dengan memberikan wewenang kepada setiap wajib pajak untuk menghitung dan membayar sendiri pajak terutang. Wewenang tersebut berindikasi dapat menimbulkan manipulasi dalam pelaporan SPT oleh wajib pajak. Oleh sebab itu, kinerja Kantor Pelayanan Pajak (KPP) yang optimal dapat membuat penerimaan pajak tetap mencapai target walaupun Self Assessement System diterapkan di Indonesia.

Sosialisasi pajak bertujuan untuk memberikan informasi terbaru mengenai perpajakan dengan pendekatan kepada masyarakat agar masyarakat memahami peraturan perpajakan dan manfaat dalam membayar pajak sehingga hal tersebut dapat meningkatkan realisasi penerimaan pajak (Kopong, Yeny \& Widyaningrum, 2017). Peluang tercapainya realisasi penerimaan pajak terbilang besar dan dapat ditingkatkan karena setiap tahun terjadi pertumbuhan penduduk yang dapat berpotensi meningkatkan jumlah wajib pajak terdaftar.

Kemajuan suatu negara bergantung pada sumbangan wajib pajak yang saat ini gencar dikejar kepatuhannya oleh pemerintah (Sari, 26 Juli 2017). Kepatuhan wajib pajak salah satunya dapat dilihat dari jumlah SPT yang dilaporkan dibandingkan dengan jumlah wajib pajak yang terdaftar. Pentingnya peran pajak memberikan tanggungjawab pula kepada wajib pajak untuk rutin dalam menyampaikan SPT. Tanggung jawab kepatuhan wajib pajak secara pribadi dapat dipandang dari sisi perilaku. Kepatuhan dan ketaatan individu dapat meningkatkan penerimaan pajak sesuai dengan Theory Planned of Behavior (Ajzen, 2012). Teori ini menjelaskan bahwa wajib pajak akan patuh atau tidak dalam kewajibannya di bidang perpajakan dengan mempertimbangkan manfaat dan pengaruh dari tindakannya dalam membayar pajak. Penurunan realisasi penerimaan pajak mengggambarkan bahwa kepatuhan wajib pajak mulai berkurang sehingga wajib pajak tidak melakukan kewajibannya sesuai UU perpajakan, seperti tidak melaporkan SPT maupun tidak melakukan perhitungan pajak terhutang dengan benar (Rahmawati et al., 2014).

\subsection{Rumusan Masalah}

Berdasarkan uraian pada latar belakang di atas maka rumusan masalah yang dapat diambil adalah sebagai berikut:

1. Apakah sosialisasi pajak berpengaruh terhadap kepatuhan wajib pajak?

2. Apakah sosialisasi pajak berpengaruh terhadap realisasi penerimaan pajak?

3. Apakah kepatuhan wajib pajak berpengaruh terhadap realisasi penerimaan pajak?

4. Apakah sosialisasi pajak berpengaruh terhadap realisasi penerimaan pajak melalui kepatuhan wajib pajak?

\section{Landasan Teori}

\subsection{Theory of Planned Behavior (TPB)}

Theory of Planned Behavior (TPB) atau teori tindakan yang direncanakan, berawal dari Theory of Reasoned Action (TRA). 
Menurut Theory of Reasoned Action, orang memiliki kontrol kehendak penuh dan memaksakan batasan yang terlalu berat pada teori yang dirancang untuk memprediksi dan menjelaskan semua perilaku penting secara sosial (Ajzen, 2012). Selanjutnya Ajzen (2012), menjelaskan bahwa Theory of Reasoned Action disangkal dengan munculnya Theory of Planned Behavior karena untuk mengakomodasi perilaku, orang mungkin memiliki kontrol kehendak yang terbatas. Menurut (Machrus \& Purwono, 2010), berdasarkan Theory of Planned Behavior tindakan manusia dibimbing oleh 3 faktor keyakinan (belief), evaluasi terhadap hasil yang diperoleh (behavior belief) keyakinan tentang harapan normative dari orang lain, motivasi (normative belief) keyakinan tentang hadirnya faktor yang memfasilitasi atau menghambat perilaku, dan persepsi adanya keyakinan (control belief).

Theory of Planned Behavior digunakan karena relevan, yaitu perilaku patuh atau tidak patuh wajib pajak dalam memenuhi kewajiban perpajakannya dipengaruhi oleh niat yang dimiliki oleh wajib pajak. Berdasarkan teori ini apabila wajib pajak memiliki niat untuk patuh terhadap kewajiban perpajakannya maka akan terjadi perilaku yang patuh terhadap pajak.

Relevansi Theory of Planned Behavior dengan penelitian ini selain dengan kepatuhan wajib pajak, juga relevan dengan variabel bebas yaitu sosialisasi pajak. Berdasarkan Theory of Planned Behavior yaitu Normatif Belief, motivasi dari kegiatan sosialisasi dari ekstensifikasi pajak dapat menimbulkan kepatuhan wajib pajak. Normatif belief atau keyakinan normatif yaitu keyakinan tentang harapan normatif orang lain dan motivasi untuk memenuhi harapan tersebut yang mengakibatkan tekanan sosial yang dirasakan atau norma subjektif
(Ajzen, 2012). Selanjutnya, keyakinan normatif (normative belief) mengakibatkan terbentuknya persepsi adanya tekanan sosial untuk melakukan tindakan atau norma subjektif. Sehingga sosialisasi pajak berpengaruh positif terhadap kepatuhan wajib pajak.

\subsection{Realisasi Penerimaan Pajak}

Realisasi penerimaan pajak adalah penerimaan pajak yang berasal dari wajib pajak yang berhasil dihimpun oleh KPP (Darmayani \& Herianti, 2017). Apabila penerimaan pajak tinggi maka dapat dikatakan suatu negara telah mandiri untuk membiayai pembangunannya dan semakin kecil ketergantungannya terhadap bantuan asing seperti hutang luar negeri maupun hibah (Lesmana et al., 2018). Penerimaan pajak yang dapat terealisasi secara mandiri akan membuat negara berkembang dengan bebas tanpa beban hutang asing. Sumber mandiri tersebut dapat didapatkan oleh negara melalui sektor pajak.

Kenaikan penerimaan pajak dari tahun ke tahun menunjukan bahwa terdapat potensi besar di sektor perpajakan (Rahmawati et al., 2014). Selanjutnya (Rahmawati et al., 2014), menjelaskan bahwa target penerimaan pajak akan selalu mengalami kenaikan setiap tahunnya seiring dengan kegiatan ekstensifikasi dalam mengumpulkan wajib pajak baru yang dilakukan oleh KPP. Seharusnya semakin banyak wajib pajak baru maka akan semakin banyak orang yang membayar pajak sehingga ekstensifikasi pajak melalui proses sosialisasi pajak berpengaruh positif terhadap penerimaan pajak. Namun, ternyata penerimaan pajak tidak selalu mencapai target dan dapat mengalami penurunan.

Penurunan penerimaan pajak menggambarkan bahwa kepatuhan wajib pajak mulai mengalami penurunan 
sehingga tidak melakukan kewajibannya sesuai UU perpajakan, seperti tidak melaporkan SPT maupun tidak melakukan perhitungan pajak terhutangnya dengan benar (Rahmawati et al., 2014). Penerimaan dari sektor perpajakan masih belum optimal karena masih minimnya tingkat kesadaran dan kepatuhan wajib pajak dalam membayar pajak (Lesmana et al., 2018). Selanjutnya (Lesmana et al., 2018), menjelaskan bahwa melesetnya target penerimaan pajak dalam tujuh tahun terakhir dikarenakan lemahnya regulasi perpajakan dalam meningkatkan tingkat kepatuhan pajak. Maka dari itu erat kaitannya kepatuhan wajib pajak dengan penerimaan pajak. Sehingga apabila kepatuhan wajib pajak tinggi maka realisasi penerimaan pajak juga akan tinggi.

\subsection{Sosialisasi Pajak}

Populasi masyarakat Indonesia yang sangat banyak menjadikan potensi pajak sangat tinggi (Rahmawati et al., 2014). Namun demikian kesadaran masyarakat terhadap kewajiban setiap warga negara dalam membayar pajak masih sangat rendah maka dari itu sosialisasi pajak perlu selalu dilakukan. Upaya memaksimalkan penghimpunan pajak negara dapat dilakukan melalui program ekstensifikasi di bidang perpajakan (Darmayani \& Herianti, 2017). Program ekstensifikasi pajak tersebut dapat diwujudkan melalui sosialisasi pajak.

Upaya yang dapat dilakukan untuk memaksimalkan kegiatan ekstensifikasi pajak adalah dengan melakukan sosialisasi dengan mendatangi lokasi wajib pajak dengan tujuan memberikan edukasi dan menginformasi masyarakat tentang pentingnya pajak bagi negara dengan harapan masyarakat dapat paham dan mengerti serta sadar untuk membayar pajak (Andreas \& Savitri, 2015).
Selanjutnya Andreas \& Savitri (2015) menjelaskan bahwa, sosialisasi dapat dilakukan dengan cara mendatangi wajib pajak di lokasi mereka dengan tujuan dapat memberikan informasi perpajakan yang lebih mendalam kepada wajib pajak agar paham dan mengerti peran dan fungsi pajak serta sadar untuk melaksanakan kewajiban perpajakannya.

\subsection{Kepatuhan Wajib Pajak}

Tingkat kepatuhan wajib pajak merupakan gambaran dari ketaatan, tunduk dan patuh serta melaksanakan ketentuan perpajakan (Yusuf Kastolani \& Ardiyanto, 2017). Kepatuhan wajib pajak dapat dipengaruhi oleh faktor sosialisasi pajak (Wardani \& Wati, 2018). Kepatuhan wajib pajak dapat dilihat dari perbandingan wajib pajak yang menyerahkan SPT dengan jumlah wajib pajak yang terdaftar (Rahmawati et al., 2014). Menurut UU Nomor 28 tahun 2007 Pasal 1 ayat 11, SPT adalah surat yang oleh wajib pajak digunakan untuk melaporkan penghitungan dan pembayaran pajak, objek pajak dan bukan objek pajak, harta dan kewajiban sesuai peraturan peratuan perundang-undangan perpajakan. Wajib pajak yang terdaftar dengan mendaftarkan NPWP membuat wajib pajak menjadi wajib dalam melaporkan SPT. Jika seseorang telah terdaftar NPWP maka hal tersebut akan membangun kesadaran wajib pajak untuk membayar kewajiban pajaknya kepada negara yang dapat meningkatkan (Andreas \& Savitri, 2015).

Kepatuhan wajib pajak sangat dibutuhkan untuk mengoptimalkan penerimaan pajak di Indonesia (Darmayani \& Herianti, 2017). Kepatuhan wajib pajak merupakan salah satu faktor penentu untuk meningkatkan penerimaan pajak yang dapat dilihat dari SPT yang dilaporkan dengan tepat waktu. Semakin tinggi tingkat kepatuhan maka akan 
berpengaruh secara langsung terhadap peningkatan penerimaan pajak (Yusuf Kastolani \& Ardiyanto, 2017). Diterapkannya sistem Self Assesement membutuhkan kepatuhan sukarela dari wajib pajak yang diwujudkan jika unsur kesadaran perpajakan dan unsur penegakan tindakan hukum dapat terpenuhi (Darmayani \& Herianti, 2017). Apabila kedua unsur tersebut terpenuhi maka ketidakpatuhan wajib pajak dapat ditekan untuk meningkatkan penerimaan pajak.

\subsection{Pengaruh Sosialisasi Pajak terhadap Kepatuhan Wajib Pajak}

Menjangkau wajib pajak baru adalah salah satu cara untuk memperluas subjek dan objek pajak (Andreas \& Savitri, 2015). Salah satu kemudahan dalam menjangkau wajib pajak baru tersebut adalah dengan melalui sosialisasi pajak. Menurut (Wardani \& Wati, 2018), intensitas sosialisasi pajak yang direspon dengan baik oleh masyarakat memberikan pengaruh besar terhadap pengaruh sosialisasi pajak terhadap kepatuhan wajib pajak. Selain itu, berdasarkan Theory of Planned Behavior yaitu Normatif Belief, motivasi yang didapatkan dari kegiatan sosialisasi pajak dapat menimbulkan kepatuhan dalam diri wajib pajak.

Normative belief atau keyakinan normatif yaitu keyakinan tentang harapan normatif orang lain dan motivasi untuk memenuhi harapan tersebut yang mengakibatkan tekanan sosial yang dirasakan atau norma subjektif (Ajzen, 2012). Selanjutnya, keyakinan normatif (normative belief) mengakibatkan terbentuknya persepsi adanya tekanan sosial untuk melakukan tindakan atau norma subjektif. Sehingga sosialisasi pajak berpengaruh positif terhadap kepatuhan wajib pajak. Hasil tersebut sesuai dengan penelitian dari (Andreas \& Savitri, 2015) yang mengatakan bahwa sosialisasi pajak berpengaruh terhadap kepatuhan wajib pajak. Sehingga hipotesis yang dapat dirumuskan adalah:

H1: Sosialisasi pajak berpengaruh positif terhadap kepatuhan wajib pajak.

\subsection{Pengaruh Sosialisasi Pajak terhadap Realisasi Penerimaan Pajak}

Penerimaan pajak merupakan sumber yang dapat diandalkan dari suatu negara berkembang seperti Indonesia. Apabila sumber subjek dan objek pajak dapat diperluas maka sumber penerimaan pajak juga akan bertambah. Kegiatan sosialisasi pajak yang dilakukan untuk memperluas potensi wajib pajak baru tentu dapat diandalkan karena jumlah masyarakat yang semakin bertambah. Sosialisasi pajak merupakan hal yang sangat penting dilakukan oleh DJP untuk bertujuan memberikan pemahaman kepada masyarakat mengenai perpajakan tentang pentingnya membayar pajak karena semakin banyak masyarakat yang paham mengenai pajak, maka akan semain banyak peningkatan penerimaan pajak (Kopong, Yeny \& Widyaningrum, 2017).

Menurut Theory of Planned Behavior (TPB) yaitu keyakinan perilaku atau behavior belief perilaku manusia dipengaruhi oleh berhasil atau tidak berhasilnya suatu tindakan terhadap diri individu tersebut sesuai dengan alasan dilakukannya suatu tindakan. Sikap wajib pajak dalam membayar pajak yang benar dan tepat waktu dapat dengan cepat menaikan realisasi penerimaan pajak (Darmayani \& Herianti, 2017). Maka, apabila wajib pajak yakin bahwa realisasi penerimaan pajak tersebut berguna untuk dirinya sendiri maka wajib pajak tersebut akan mematuhi peraturan perpajakan. Cara wajib pajak mematuhi peraturan perpajakan yaitu dengan benar dan tepat dalam menyampaikan SPT sehingga wajib pajak dapat dikatakan patuh. Apabila kepatuhan wajib pajak dapat 
ditingkatkan maka realisasi penerimaan pajak juga akan semakin meningkat pula. Apabila wajib pajak semakin meningkat dan wajib pajak semakin paham mengenai manfaat dari perpajakan, maka sumber penerimaan pajak juga akan semakin meningkat. Sehingga Sosialisasi pajak dapat berpengaruh secara langsung terhadap penerimaan pajak. Seperti penelitian (Kurnia et al., 2015) yang mengatakan bahwa sosialisasi pajak berpengaruh terhadap penerimaan pajak. Maka hipotesis yang dapat dirumuskan adalah:

$\mathrm{H} 2$ : Sosialisasi pajak berpengaruh positif terhadap realisasi penerimaan pajak.

\subsection{Pengaruh Kepatuhan Wajib Pajak terhadap Realisasi Penerimaan Pajak}

Penurunan penerimaan pajak menggambarkan bahwa kepatuhan wajib pajak mulai terhambat sehingga tidak melakukan kewajibannya sesuai UU perpajakan, seperti tidak melaporkan SPT maupun tidak melakukan perhitungan pajak terhutangnya dengan benar (Rahmawati et al., 2014). Maka dari itu erat kaitannya kepatuhan wajib pajak dengan penerimaan pajak. Sehingga apabila kepatuhan wajib pajak tinggi maka pencapaian target penerimaan pajak juga akan tinggi.

Theory of Planned Behavior adalah salah satu teori perilaku yang sering digunakan untuk menjelaskan perilaku kepatuhan (Lesmana et al., 2018). Teori ini menjelaskan bahwa perilaku seseorang dipengaruhi oleh niat yang dimiliki. Sementara niat seseorang dibentuk oleh sikap terhadap terilaku (Attitude Toward the Behavior), norma subjektif, dan kontrol keperilakuan yang dipersepsikan melalui keyakinan yang dimilikinya. Berdasarkan control belief atau keyakinan kontrol membuat motivasi untuk menuruti dari adanya suatu harapan (Ajzen, 2012).
Motivasi untuk menuruti suatu harapan tersebut timbul setelah dilakukan sosialisasi pajak. Apabila wajib pajak tersebut termotivasi dari sosialisasi pajak tersebut maka wajib pajak akan mematuhi aturan perpajakan. Sosialisasi pajak digunakan untuk menyampaikan informasi terbaru mengenai perpajakan agar masyarakat mengetahui tentang pentingnya realisasi penerimaan pajak sehingga dapat dikatakan sumber realisasi penerimaan pajak akan meningkat seiring dengan semakin meningkatnya pula pertumbuhan penduduk yang berpotensi menjadi wajib pajak atau subjek pajak. Ketidakpatuhan wajib pajak timbul karena pada dasarnya tidak ada orang yang rela untuk membayar pajak (Darmayani \& Herianti, 2017). Namun, jika ketidakpatuhan dapat dihindari maka akan membuat hubungan yang berbeda terhadap penerimaan pajak. Jadi, erat kaitanya antara kepatuhan wajib pajak dan penerimaan pajak. Seperti penelitian dari (Rahmawati et al., 2014), Kastolani \& Ardiyanto (2017), dan Darmayani \& Herianti (2017) yang mengatakan bahwa kepatuhan wajib pajak berpengaruh terhadap penerimaan pajak. Sehingga hipotesis yang dapat dirumuskan adalah:

H3: Kepatuhan wajib pajak berpengaruh positif terhadap realisasi penerimaan pajak.

\subsection{Pengaruh Sosialisasi Pajak terhadap Realisasi Penerimaan Pajak melalui Kepatuhan Wajib Pajak}

Kenaikan penerimaan pajak dari tahun ke tahun menunjukan bahwa terdapat potensi besar di sektor perpajakan (Rahmawati et al., 2014). Sosialisasi pajak dapat mendorong kepatuhan wajib pajak. Kegiatan yang dapat dilakukan untuk ekstensifikasi pajak dapat dilakukan dengan cara sosialisasi pajak. Kepatuhan wajib pajak dapat didorong dengan kemudahan dalam memperoleh informasi 
melalui sistem perpajakan (Lesmana et al., 2018). Informasi yang tepat tersebut berguna untuk menjangkau wajib pajak baru. Jika wajib Pajak patuh, maka penerimaan pajak akan mencapai target yang diinginkan.

Penerimaan dari sektor perpajakan yang masih belum optimal karena masih minimnya tingkat kesadaran dan kepatuhan wajib pajak dalam membayar pajak (Lesmana et al., 2018). Maka dari itu erat kaitannya kepatuhan wajib pajak dengan penerimaan pajak. Sehingga apabila kepatuhan wajib pajak tinggi maka pencapaian target penerimaan pajak juga akan tinggi.

Machrus \& Purwono (2010) juga menjelaskan bahwa, berdasarkan Theory of Planned Behavior, keyakinan perilaku (behavior belief) menimbulkan sikap positif dan negatif terhadap perilaku tertentu. Selanjutnya, keyakinan normatif (normative belief) mengakibatkan terbentuknya persepsi adanya tekanan sosial untuk melakukan tindakan atau norma subjektif. Berdasarkan Normatif Belief, motivasi dari kegiatan ekstensifikasi pajak dapat menimbulkan kepatuhan wajib pajak. Sedangkan menurut keyakinan kontrol (control belief), apabila wajib pajak mengetahui pentingnya perpajakan maka wajib pajak akan mengetahui pula pentingnya membayar pajak dan diikuti dengan tindakan mendaftarkan diri sebagai wajib pajak. Maka hipotesis yang dapat dirumuskan adalah:

H4: Sosialisasi pajak berpengaruh positif terhadap realisasi penerimaan pajak melalui kepatuhan wajib pajak.

\section{METODE PENELITIAN}

\subsection{Metodologi Penelitian}

Penelitian ini merupakan penelitian yang menggunakan pendekatan kuantitatif. Sedangkan metode yang digunakan dalam penelitian ini adalah metode eksplanatori. Maka penelitian ini merupakan penelitian eksplanatori dengan pendekatan kuantitatif. Berikut merupakan rancangan penelitian yang digunakan:

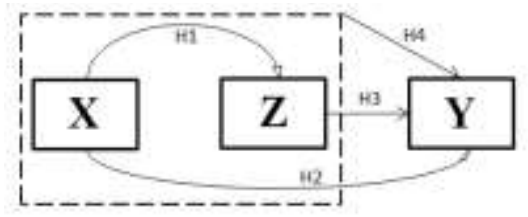

Gambar 3.1 Rancangan Penelitian

Keterangan:

$\mathrm{X} \quad$ : Sosialisasi Pajak

Y : Realisasi Penerimaan Pajak

$\mathrm{Z}$ : Kepatuhan Wajib Pajak

$\rightarrow \quad$ : Pengaruh langsung

$-->\quad$ : Pengaruh tidak langsung

\subsection{Definisi Operasional Dan Pengukuran Variabel}

Penelitian ini menggunakan 3 jenis variabel penelitian yaitu variabel bebas, terikat dan intervening. Berikut merupakan definisi operasional variabel penelitian:

1. Realisasi Penerimaan Pajak (Y)

Penerimaan pajak merupakan sumbangan yang dapat dipaksakan oleh DJP kepada wajib pajak berdasarkan objek pajak yang dikenakan. Penerimaan pajak ditargetkan berdasar jumlah kebutuhkan dana yang tercatat dalam APBN yang harus dipenuhi dari sektor pajak. Target penerimaan pajak tersebut selanjutnya harus dipenuhi oleh masingmasing Kantor Pelayanan Pajak. Menurut penelitian Darmayani \& Herianti (2017), realisasi penerimaan pajak adalah penerimaan pajak yang berasal dari wajib pajak yang berhasil dihimpun oleh KPP dari target. Menurut pengertian tersebut maka rumus yang dapat digunakan adalah:

$\frac{\text { Realisasi Penerimaan Pajak }}{\text { Target Penerimaan Pajak }} \times 100 \%$
2. Kepatuhan Wajib Pajak (Z)

Menurut Kastolani dan Ardiyanto 
(2017), Kepatuhan wajib pajak dapat diwujudkan dengan secara tepat waktu menyampaikan SPT. Wajib pajak yang memenuhi syarat objektif dan syarat subjektif dapat mendaftarkan diri sebagai wajib pajak. Setelah terdaftar menjadi wajib pajak, kewajiban selanjutnya adalah dengan rutin menyampaikan SPT. Ada dua jenis SPT, yaitu SPT tahunan dan SPT masa. Indikator yang digunakan dalam penelitian ini adalah menggunakan SPT masa karena analisis dilakukan perbulan. Menurut Surat Edaran Dirjen Pajak nomor SE18/PJ/2006 tentang Key Performance Indicator, pada ayat 3 yang menjelaskan Key Performance Indicator untuk penyampaian SPT masa dapat dihitung dengan cara membandingkan SPT masa yang dilaporkan dibandingkan dengan jumlah wajib pajak terdaftar pada periode tertentu. Key Performance Indicator ini juga dapat digunakan untuk menghitung SPT masa dengan rumus:

$=\frac{\text { SPT masa yang dilaporkan }}{\text { Jumlah WP terdaftar wajib SPT }} \times 100 \%$

3. Sosialisasi Pajak (X)

Ekstensifikasi pajak merupakan cara meningkatkan penerimaan pajak dengan memperluas atau menambah jumlah wajib pajak baru. Kegiatan ekstensifikasi dengan sosialisasi pajak dapat dilakukan dengan menambah jumlah wajib pajak terdaftar dan memperluas objek pajak sehingga mampu meningkatkan penerimaan pajak yang dilakukan dengan melalui sosialisasi pajak. Seksi ekstensifikasi pajak memiliki daftar sasaran sosialisasi. Menurut peraturan direktur jenderal pajak nomor PER35/PJ/2013 pasal 1 ayat 10 tentang tata cara ekstensifikasi, daftar sasaran ekstensifikasi dengan sosialisasi pajak adalah daftar wajib pajak yang telah memenuhi syarat subjektif dan objektif dan belum mendaftarkan diri untuk diberikan yang disusun dari hasil analisis data dan informasi yang dimiliki dan diperoleh KPP. Menurut Munarianto (wawancara, 28 Juli 2019), sasaran wajib pajak hasil sosialisasi pajak didapatkan dari jumlah seseorang yang mengikuti atau menjadi peserta sosialisasi pajak yang belum memiliki NPWP dan masuk dalam kriteria subjek pajak sesuai UU no. 28 tahun 2007. Menurut penjelasan tersebut maka rumus yang dapat digunakan untuk menghitung presentase jumlah wajib pajak baru hasil sosialisasi pajak adalah:

$=\frac{\text { Realisasi jumlah wajib pajak baru }}{\text { Sasaran jumlah wajib pajak baru }} \times 100 \%$

\subsection{Subjek Penelitian}

Subjek penelitian dalam penelitian ini adalah KPP Pratama Kepanjen. KPP Pratama Kepanjen dipilih menjadi tempat penelitian karena berada di bawah DJP Jatim III yang berada pada peringkat II nasional penerimaan pajak tertinggi pada tahun 2017 setelah DJP Jabar II (Kusbandono, 2018). DJP Jatim III dipilih karena pertimbangan wilayah, jarak, dan biaya dibandingkan dengan DJP Jabar II. Lokasi tersebut dipilih karena diharapkan dengan posisi peringkat tertinggi tersebut dapat menjelaskan pengaruh dari sosialisasi pajak terhadap realisasi penerimaan pajak yang melebihi target tersebut.

\section{HASIL DAN PEMBAHASAN \\ 4.1 Statistik Deskriptif}

Penelitian ini menggunakan analisis jalur (path) dalam mengolah data penelitian. Data yang digunakan dalam penelitian adalah sosialisasi pajak (X), realisasi penerimaan pajak (Y) dan kepatuhan wajib pajak (Z) yang bersumber dari Kantor Pelayanan Pajak Pratama Kepanjen. Data didapatkan dengan menghitung indikator variabel 
sehingga didapat data dalam bentuk presentase. Tingkat sosialisasi pajak yang dihitung dengan membandingkan data realisasi dan sasaran wajib pajak hasil sosialisasi pajak, presentase tingkat realisasi penerimaan pajak yang dihitung dengan membandingkan data realisasi dan target penerimaan pajak dan presentase tingkat kepatuhan wajib pajak yang dihitung dengan membandingkan data SPT dilaporkan dengan wajib pajak terdaftar SPT.

Tabel 4.1 Statistik Deskriptif Variabel Penelitian

\begin{tabular}{|l|c|l|l|l|l|}
\hline & N & Min & Max & Mean & $\begin{array}{l}\text { Std. } \\
\text { Dev. }\end{array}$ \\
\hline $\begin{array}{l}\text { Sosialisasi } \\
\text { Pajak }\end{array}$ & 60 & 63,70 & 325,39 & 135,09 & 50,38 \\
\hline $\begin{array}{l}\text { Kepatuhan } \\
\text { Wajib } \\
\text { Pajak }\end{array}$ & 60 & 50,37 & 103,29 & 75,85 & 12,25 \\
\hline $\begin{array}{l}\text { Realisasi } \\
\text { Penerimaan } \\
\text { Pajak }\end{array}$ & 60 & 65,56 & 120,59 & 90,45 & 14,19 \\
\hline
\end{tabular}

Sumber: KPP Pratama Kepanjen (Data yang diolah, 2019)

\subsection{Pengujian Asumsi Analisis Data 4.2.1 Uji Normalitas}

Uji normalitas variabel bertujuan untuk menguji apakah data variabel dependen, independen dan intervening terdistribusi dengan normal atau tidak. Metode yang digunakan untuk menguji normalitas pada penelitian ini adalah uji KolmogorovSmirnov. Pada uji Kolmogorov-Smirnov apabila nilai signifikansi hasil uji lebih besar dari 0,05 maka data penelitian berdistribusi normal dan apabila sebaliknya yaitu nilai signifikasi lebih kecil dari 0.05 maka data penelitian tidak terdistrbusi dengan normal. Hasil pengujian disajikan sebagai berikut:

Tabel 4.2 Hasil Uji Normalitas Variabel Penelitian

\begin{tabular}{|l|c|l|l|}
\hline $\begin{array}{c}\text { Variabel } \\
\text { Penelitian }\end{array}$ & $\begin{array}{c}\text { Kolmogorov- } \\
\text { Smirnov Z }\end{array}$ & Sig. & Ket \\
\hline $\begin{array}{l}\text { Sosialisasi } \\
\text { Pajak }\end{array}$ & 1,152 & 0,141 & Normal \\
\hline $\begin{array}{l}\text { Kepatuhan } \\
\text { Wajib } \\
\text { Pajak }\end{array}$ & 0,508 & 0,959 & Normal \\
\hline $\begin{array}{l}\text { Realisasi } \\
\text { Penerimaan } \\
\text { Pajak }\end{array}$ & 0,736 & 0,651 & Normal \\
\hline
\end{tabular}

Sumber: Data yang diolah, 2019

\subsubsection{Uji Heteroskedastisitas}

Metode yang dapat dipakai untuk mendeteksi gejala heteroskedastisitas dalam penelitian ini adalah metode grafik scatter plot. Jika pencaran data yang berupa titik-titik tidak membentuk pola tertentu dan menyebar di atas dan di bawah sumbu Y, maka tidak terjadi masalah heteroskedastisitas.
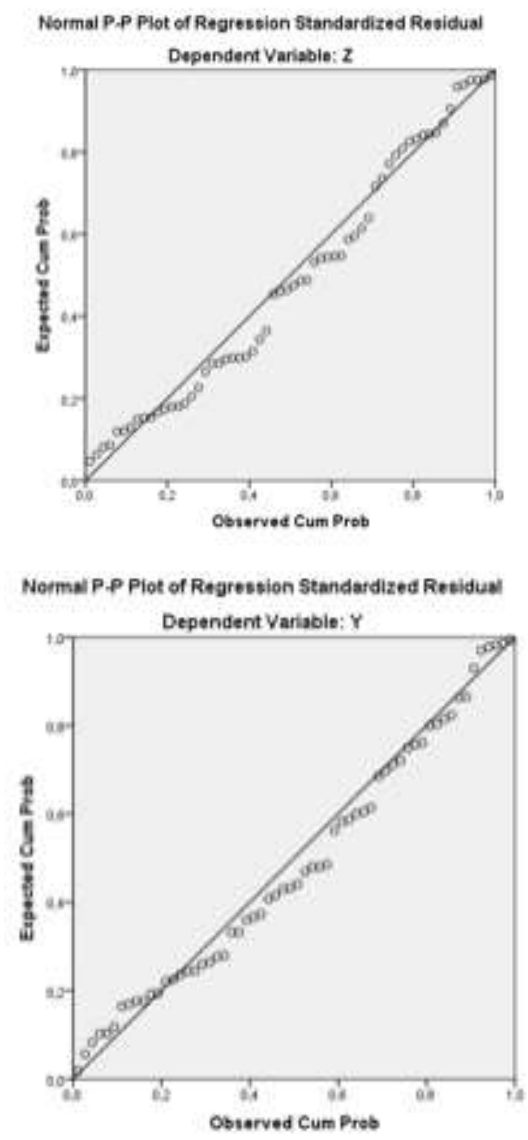

Gambar 4.1 Uji Heteroskedastisitas dengan Scatter Plot

Sumber: Data yang diolah, 2019 
Hasil uji heteroskedastisitas menggunakan scatter plot menunjukkan bahwa titik-titik menyebar secara acak dan tidak membentuk pola tertentu. Titiktitik tersebut menyebar diantara nilai nol maka data dikatakan telah terdistribusi dengan normal dan tidak terjadi heteroskedastisitas. Hal ini menunjukkan bahwa tidak terdapat indikasi adanya heteroskedastisitas pada model yang diuji sehingga asumsi ini terpenuhi.

\subsection{Analisis Jalur (Path)}

Analisis jalur merupakan pengembangan dari analisis korelasi yang dibangun dari diagram jalur yang dihipotesiskan oleh peneliti dalam menjelaskan mekanisme pengaruh antar variabel dengan menguraikan koefisien korelasi menjadi pengaruh langsung dan pengaruh tidak langsung. Pengujian model jalur dilakukan untuk menguji ada tidaknya pengaruh dari variabel bebas terhadap variabel terikat baik secara langsung maupun tidak langsung.

Tabel 4.3 Pengaruh Antar Variabel dan Persamaan Jalur

\begin{tabular}{|c|c|c|c|c|}
\hline Pengaruh & $\begin{array}{c}\text { Koefisien } \\
\text { Jalur }\end{array}$ & $\begin{array}{c}\text { t- } \\
\text { hitung }\end{array}$ & sig & $\mathbf{R}^{\mathbf{2}}$ \\
\hline $\mathrm{X} \rightarrow \mathrm{Z}$ & 0,538 & 4,858 & 0,000 & $28,9 \%$ \\
\hline Total & & & & $28,9 \%$ \\
\hline $\mathrm{X} \rightarrow \mathrm{Y}$ & 0,311 & 2,392 & 0,020 & $15,3 \%$ \\
\hline $\mathrm{Z} \rightarrow \mathrm{Y}$ & 0,329 & 2,527 & 0,014 & $16,2 \%$ \\
\hline Total & & & & $31,5 \%$ \\
\hline
\end{tabular}

Keterangan: $\mathrm{X}=$ Sosialisasi Pajak, $\mathrm{Z}=$ Kepatuhan Wajib Pajak, Y = Realisasi Penerimaan Pajak

Sumber: Data yang diolah, 2019

Untuk mengetahui apakah pengaruh antar variabel tersebut positif atau negatif maka dapat dilihat dari nilai pada kolom koefisien jalur. Apabila nilai pada kolom tersebut positif maka variabel tersebut memiliki pengaruh yang positif terhadap variabel yang dipengaruhi dan sebaliknya.
Sedangkan untuk melihat nilai apakah variabel satu memiliki pengaruh terhadap variabel yang dipengaruhi secara signifikan atau tidak dapat dilihat dari kolom signifikasi. Nilai pada kolom tersebut harus kurang dari 0.05 maka dapat dikatakan memiliki pengaruh yang signifikan. Sedangkan kolom $\mathrm{R}^{2}$ menunjukan besar pengaruh dalam bentuk satuan presentase.

\subsection{Koefisien Determinasi Total}

Koefisien determinasi total menjelaskan mengenai seberapa besar model jalur (path) yang terbentuk dalam menjelaskan data yang digunakan dalam penelitian. Besar nilai koefisien determinasi berkisar antara 0\% hingga $100 \%$, di mana semakin tinggi koefisien determinasi maka semakin baik pula model dalam menjelaskan data yang digunakan.

$$
\mathrm{R}_{\mathrm{m}}^{2}=1-[(1-0,289) \times(1-0,315)]=
$$
0,513

Koefisien determinasi total yang didapatkan berdasarkan hasil perhitungan model path adalah sebesar 0,513 yang menunjukkan bahwa model path yang digunakan dapat menjelaskan sebesar $51,3 \%$ data yang digunakan dalam penelitian.

\subsection{Pengujian Hipotesis}

Pada penelitian ini terdapat 3 pengaruh langsung dan 1 pengaruh tidak langsung dari analisis yang dilakukan. Berikut disajikan hasil pengujiannya.

Tabel 4.4 Pengaruh Langsung

\begin{tabular}{|c|c|c|c|c|}
\hline Pengaruh & $\begin{array}{c}\text { Koefisien } \\
\text { Jalur }\end{array}$ & $\begin{array}{c}\text { Standar } \\
\text { Error }\end{array}$ & $\begin{array}{c}\mathbf{t}- \\
\text { hitung }\end{array}$ & Sig \\
\hline $\mathrm{X} \rightarrow \mathrm{Z}$ & 0,538 & 0,027 & 4,858 & 0,000 \\
$\mathrm{X} \rightarrow \mathrm{Y}$ & 0,311 & 0,037 & 2,392 & 0,020 \\
$\mathrm{Z} \rightarrow \mathrm{Y}$ & 0,329 & 0,151 & 2,527 & 0,014 \\
\hline
\end{tabular}

Keterangan: $\mathrm{X}=$ Sosialisasi Pajak, $\mathrm{Z}=$

Kepatuhan Wajib Pajak, Y = Realisasi

Penerimaan Pajak

Sumber: Data yang diolah, 2019 
Hasil pengujian pengaruh langsung Sosialisasi Pajak terhadap Kepatuhan Wajib Pajak diperoleh t-hitung $(4,858)$ yang lebih besar dari t-tabel $(2,002)$ atau signifikansi $(0,000)$ lebih kecil dari alpha $5 \%(0,050)$ maka disimpulkan terdapat pengaruh positif dan signifikan Sosialisasi Pajak terhadap Kepatuhan Wajib Pajak. Semakin baik Sosialisasi Pajak maka Kepatuhan Wajib Pajak akan semakin meningkat atau sebaliknya semakin tidak baik Sosialisasi Pajak maka Kepatuhan Wajib Pajak akan semakin menurun.

Hasil pengujian langsung Sosialisasi Pajak terhadap Realisasi Penerimaan Pajak diperoleh t-hitung $(2,392)$ yang lebih besar dari t-tabel $(2,002)$ atau signifikansi $(0,020)$ lebih kecil dari alpha $5 \%(0,050)$ maka disimpulkan terdapat pengaruh positif dan signifikan Sosialisasi Pajak terhadap Realisasi Penerimaan Pajak. Semakin baik Sosialisasi Pajak maka Realisasi Penerimaan Pajak akan semakin meningkat atau sebaliknya semakin tidak baik Sosialisasi Pajak maka Realisasi Penerimaan Pajak akan semakin menurun.

Hasil pengujian langsung Kepatuhan Wajib Pajak terhadap Realisasi Penerimaan Pajak diperoleh t-hitung $(2,527)$ yang lebih besar dari t-tabel $(2,002)$ atau signifikansi $(0,014)$ lebih kecil dari alpha 5\% $(0,050)$ maka disimpulkan terdapat pengaruh positif dan signifikan Kepatuhan Wajib Pajak terhadap Realisasi Penerimaan Pajak. Semakin tinggi Kepatuhan Wajib Pajak maka Realisasi Penerimaan Pajak akan semakin meningkat atau sebaliknya semakin rendah Kepatuhan Wajib Pajak maka Realisasi Penerimaan Pajak akan semakin menurun.
Tabel 4.5 Pengaruh Tidak Langsung

\begin{tabular}{|c|c|c|c|c|}
\hline Pengaruh & $\begin{array}{c}\text { Koefisien } \\
\text { Jalur }\end{array}$ & $\begin{array}{c}\text { Standar } \\
\text { Error }\end{array}$ & t-hitung & Sig. \\
\hline $\mathrm{X} \rightarrow \mathrm{Z}$ & 0,538 & 0,027 & 4,858 & 0,000 \\
\hline $\mathrm{Z} \rightarrow \mathrm{Y}$ & 0,329 & 0,151 & 2,527 & 0,014 \\
\hline $\mathrm{X} \rightarrow \mathrm{Z} \rightarrow$ & $\begin{array}{c}0,538 \mathrm{x} \\
0,329\end{array}$ & $\begin{array}{c}\sqrt{ }\left(0,538^{2}\right. \\
\mathrm{x} 0,151^{2} \\
+0,329^{2}\end{array}$ & $\begin{array}{c}0,177 / 0,082 \\
=2,166\end{array}$ & 0,035 \\
$\mathrm{Y}$ & 0,177 & $\begin{array}{c}\left.\mathrm{x} 0,027^{2}\right) \\
=0,082\end{array}$ & & \\
& & & \\
\end{tabular}

Keterangan: $\mathrm{X}=$ Sosialisasi Pajak, $\mathrm{Z}=$ Kepatuhan Wajib Pajak, Y = Realisasi Penerimaan Pajak

Sumber: Data yang diolah, 2019

Hasil pengujian pengaruh tidak langsung Sosialisasi Pajak terhadap Realisasi Penerimaan Pajak melalui Kepatuhan Wajib Pajak dipeoleh t-hitung $(2,166)$ yang lebih besar dari t-tabel $(2,002)$ atau signifikansi $(0,035)$ lebih kecil dari alpha 5\% $(0,050)$ maka disimpulkan terdapat pengaruh tidak langsung yang signifikan dengan arah positif antara Sosialisasi Pajak terhadap Realisasi Penerimaan Pajak melalui Kepatuhan Wajib Pajak. Artinya, apabila Sosialisasi Pajak semakin baik diikuti dengan Kepatuhan Wajib Pajak yang semakin tinggi maka Realisasi Penerimaan Pajak akan semakin meningkat. Sebaliknya apabila Sosialisasi Pajak semakin tidak baik diikuti dengan Kepatuhan Wajib Pajak yang semakin rendah maka Realisasi Penerimaan Pajak akan semakin menurun. Berikut ini disajikan diagram path berdasarkan hasil analisis yang telah dilakukan.

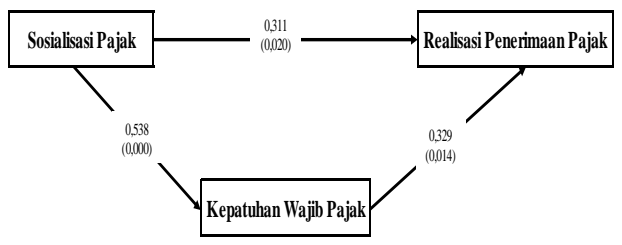

Gambar 4.2 Diagram Jalur Path

Sumber: Data yang diolah, 2019 


\section{PENUTUP}

\subsection{Kesimpulan}

Intensitas sosialisasi pajak yang direspon dengan baik oleh calon wajib pajak memberikan dampak yang besar terhadap pengaruh sosialisasi pajak terhadap kepatuhan wajib pajak. Berdasarkan Theory of Planned Behavior yaitu Normatif Belief, motivasi dari kegiatan sosialisasi pajak dapat menimbulkan kepatuhan wajib pajak. Sehingga apabila KPP Pratama Kepanjen melakukan sosialisasi pajak, maka akan terbentuk suatu tekanan sosial bagi calon wajib pajak untuk memperoleh NPWP dan menjalankan peraturan perpajakan sehingga hal tersebut dapat menimbulkan kepatuhan wajib pajak.

Jumlah wajib pajak semakin meningkat dengan pemahaman pentingnya perpajakan yang baik, maka hal tersebut dapat menjadi sumber realisasi penerimaan pajak. Sosialisasi pajak digunakan untuk menyampaikan informasi terbaru mengenai perpajakan agar masyarakat mengetahui tentang pentingnya realisasi penerimaan pajak sehingga dapat dikatakan sumber realisasi penerimaan pajak akan meningkat seiringan dengan semakin meningkatnya pula pertumbuhan penduduk yang berpotensi menjadi wajib pajak atau subjek pajak.

Peningkatan realisasi penerimaan pajak menggambarkan bahwa kepatuhan wajib pajak mulai meningkat sehingga perubahan yang terjadi terhadap kepatuhan wajib pajak juga berpengaruh terhadap realisasi penerimaan pajak. Semakin tinggi tingkat kepatuhan wajib pajak maka akan berpengaruh terhadap peningkatan realisasi penerimaan pajak.

Sosialisasi pajak yang memiliki intensitas tinggi dan diikuti dengan kepatuhan wajib pajak yang semakin tinggi dapat meningkatkan realisasi penerimaan pajak atau sebaliknya.
Berdasarkan Theory of Planned Behavior, keyakinan perilaku (behaviour belief) dari hasil sosialisasi pajak dapat menimbulkan tekanan kepada calon wajib pajak untuk memperoleh NPWP dan mematuhi peraturan perpajakan seperti menghitung dan melaporkan SPT dengan benar sehingga target penerimaan pajak dapat terealisasi.

\subsection{Saran}

Saran untuk penelitian selanjutnya adalah sebaiknya menggunakan cara mengambil data yang lain yaitu data primer atau menggunakan jenis penelitian lain seperti penelitian kualitatif menggunakan teknik wawancara. Jenis penelitian tersebut dapat mengatasi masalah dalam kesulitan memperoleh beberapa data non publik tersebut. Selanjutnya penelitian tersebut dapat memahami lebih jauh mengapa peneliti bersifat tidak patuh terhadap pajak dan alasannya dalam mendaftarkan diri sebagai wajib pajak.

Rekomendasi dari peneliti terhadap penelitian selanjutnya adalah karena keterbatasan dalam memperoleh data dan khususnya untuk data sekunder, sebaiknya penelitian selanjutnya meneliti lebih dalam tentang metode sosialisasi pajak yang lebih efektif digunakan di KPP Pratama Kepanjen. Hasil tersebut dapat digunakan untuk tambahan masukan kepada KPP Pratama Kepanjen mengenai metode sosialisasi pajak yang lebih efektif digunakan di KPP Pratama Kepanjen.

\section{DAFTAR PUSTAKA}

Ajzen, I. (2012). The theory of planned behavior. In Handbook of Theories of Social Psychology: Volume 1. https://doi.org/10.4135/9781446249 215.n22

Andreas, \& Savitri, E. (2015). The Effect of Tax Socialization, Tax Knowledge, Expediency of Tax ID 
Number and Service Quality on Taxpayers Compliance with Taxpayers Awareness as Mediating Variables. Procedia - Social and Behavioral Sciences. https://doi.org/10.1016/j.sbspro.201 5.11 .024

Darmayani, D., \& Herianti, E. (2017). Pengaruh Tingkat Kepatuhan Wajib Pajak Badan Terhadap Peningkatan Penerimaan Pajak Penghasilan Dengan Penagihan Pajak Sebagai Variabel Moderating (Pada KPP Pratama Cilandak Jakarta Selatan). InFestasi.

https://doi.org/10.21107/infestasi.v1 3i1.3049

Kopong, Yeny \& Widyaningrum, I. (2017). Pengaruh Reformasi Perpajakan Dan Sosialisasi Perpajakan Terhadap Penerimaan Pajak Dengan Kepatuhan Wajib Pajak Sebagai Variabel Moderating Pada Kpp Pratama Sunter Jakarta Utara. MEDIA AKUNTANSI PERPAJAKAN.

Kurnia, E. S., Kumadji, S., \& Azizah, D. F. (2015). Efektivitas Kegiatan Ekstensifikasi Perpajakan Dalam Upaya Meningkatkan Penerimaan Pajak Penghasilan Orang Pribadi (Studi pada Kantor Pelayanan Pajak Pratama Malang Selatan) Ega. Jurnal Perpajakan (JEJAK)|Vol. 6 No. 2015. https://doi.org/10.1017/CBO978110 7415324.004

Lesmana, D., Panjaitan, D., \& Maimunah, M. (2018). Tax Compliance Ditinjau dari Theory of Planned Behavior (TPB): Studi Empiris Pada Wajip Pajak Orang Pribadi dan Badan yang Terdaftar Pada KPP di Kota Palembang. InFestasi, 13, 354. https://doi.org/10.21107/infestasi.v1 3i 2.3514

Machrus, H., \& Purwono, U. (2010). Pengukuran Perilaku berdasarkan Theory of Planned Behaviour. Insan Media Psikologi. https://doi.org/10.1002/ejoc.201200 111

Rahmawati, F. N., Santoso, S., \& Hamidi, N. (2014). Pengaruh Pemeriksaan Dan Kepatuhan Wajib Pajak Terhadap Penerimaan Pajak Penghasilan Badan Di Surakarta. Jupe UNS. https://doi.org/10.1038/132817a0

Wardani, D. K., \& Wati, E. (2018). Pengaruh Sosialisasi Perpajakan Terhadap Kepatuhan Wajib Pajak Dengan Pengertahuan Perpajakan Sebagai Variabel Intervening (Studi Pada Wajib Pajak Orang Pribadi Di KPP Pratama Kebumen). Nominal, Barometer Riset Akuntansi Dan Manajemen.

https://doi.org/10.21831/nominal.v7 i1.19358

Yusuf Kastolani, O. J., \& Ardiyanto, M. D. (2017). Pengaruh Tingkat Kepatuhan Wajib Pajak dan Pemeriksaan terhadap Penerimaan Pajak Penghasilan. Diponegoro Journal of Accounting, 6(3), 669679. 